ment of agricultural land use in rural areas: a project]. Kyiv: NAAS [in Ukrainian].

9. Dobriak, D.O., Kanash, O.P. \& Rozumnyi, I.A. (2001). Klasyfikatsiia ta ekolohichne vykorystannia silskohospodarskykh zemel [Classification and ecological use of agricultural land]. Kyiv [in Ukrainian].

10. Tretiak, A.M., Tretiak, R.A. \& Shkvyr, M.I. (2001). Metodychni rekomendatsii otsinky ekolohichnoi stabilnosti ahrolandshaftiv ta silskohospodarskoho zemlekorystuvannia [Methodological recommendations for assessing the ecological stability of agro-landscapes and agricultural land use]. Kyiv: Institute of Land Management of UAAS [in Ukrainian].

11. Butenko, Ye.V. \& Bozniak, M.L. (2013). Udoskonalennia normatyvno-metodychnykh pidkhodiv shchodo otsinky ahroekolohichnoho stanu zemel mistsevoho rivnia [Improvement of normative and methodical approaches for assessing the agro-ecological status of land at the local level]. Zemleustrii, kadastr $i$ monitorynh zemel - Land management, inventory and land monitoring, 1-2, 81-86 [in Ukrainian].

12. Ekolohichnyi pasport Chernihivskoi oblasti [Ecological passport of Chernihiv region]. (n.d.). menr.gov. ua. Retrieved from https://menr.gov.ua/content/ ekologichni-pasporti-regioniv.html [in Ukrainian].

13. Dopovid pro stan navkolyshnoho pryrodnoho seredovyshcha v Chernihivskii oblasti za 2016 rik [Report on the state of the environment in Chernigiv region for 2016]. (n.d.). menr.gov.ua. Retrieved from https://menr.gov.ua/files/docs/Reg.report/Допові дь\%20Чернігівська\%202016.pdf [in Ukrainian].

\title{
PURIFICATION OF SUBSOIL WATER FROM IRON COMPOUNDS IN ZHYTOMYR REGION
}

\author{
I. Shumyhai \\ Інститут агроекології і природокористування НААН
}

\begin{abstract}
Доведено, що з усіх видів водних ресурсів найчіннішими для водопостачання є підземні прісні води, тому що в загальному аспекті вони є набагато чистішими за поверхневі, їх стік - стабільнішим, а якість (за винятком інфільтраційних) майже не залежить від погодних (сезонних) змін. Встановлено, що всі підземні водоносні горизонти України мають підвищений уміст іонів заліза, що варіює у межах 0,5-30 мг/л і більще. Аналізуючи відомі методи знезалізнення води, можна зробити висновок, що за незначної концентрації іонів заліза у вихідній воді вони доволі добре себе зарекомендували. Найпоширенішим методом знезалізнення води є фільтрування крізь зернисте завантаження з природних чи штучних матеріалів при швидкості фільтрування до $10 \mathrm{M} / г о д$.
\end{abstract}

Ключові слова: підземна вода, залізо, процес очищення.

The issue of drinking water quality is recently raised due to the fact that water consumers did not give rise to doubt its quality within long historical period. Society carefully maintained the existing water supplies by keeping the rules of water well site selection in the meadows with limited human activity and away from yards. Communities maintained cleanliness and utilization standards of the area around water wells. Today, the complete water supply of the Ukrainian

(C) I. Shumyhai, 2018 population is complicated due to low quality of water and water bodies [1,2].

Treatment of natural drinking water sources has become one of the focal problems in XXI century. The World Health Organization reports less than $1 \%$ of water supply sources available without additional purification. The main polluting factors are high concentration of the following elements:

- iron;

- manganese;

- hydrogen sulfide;

- organic matter. 
Application of methods for clearing subsoil waters from iron [11, 13]

\begin{tabular}{c|c}
\hline Method & Application conditions \\
\hline \hline Non - reagent methods & Source water has the following factors: \\
& $-\mathrm{pH} \geq 6.7 ;$ \\
& - Carbon dioxide level - up to $80 \mathrm{mg} / \mathrm{dm}^{3} ;$ \\
& - Hydrogen sulfide - up to $1 \mathrm{mg} / \mathrm{dm}^{3} ;$ \\
& - Permanganate oxydizability $-\mathrm{max} .7 \mathrm{mg} \cdot \mathrm{O}_{2} / \mathrm{dm}^{3}$ \\
\hline
\end{tabular}

Framed filtering method (recommended)

Iron content (III) is not more than $10 \%$ of total volume; concentration of iron (II) in dihydrocarbonate or carbonate form is up to $3 \mathrm{mg} / \mathrm{dm}^{3}$

\begin{tabular}{l|l}
\hline «Dry filtering» method & Iron concentration is up to $5 \mathrm{mg} / \mathrm{dm}^{3}$ \\
\hline $\begin{array}{l}\text { Simplified aeration with single } \\
\text { - stage filtering }\end{array}$ & Iron concentration is 5 to $10 \mathrm{mg} / \mathrm{dm}^{3}$ \\
\hline $\begin{array}{l}\text { Aeration and double - stage filter- } \\
\text { ing method }\end{array}$ & Iron concentration is 10 to $20 \mathrm{mg} / \mathrm{dm}^{3}$ \\
\hline
\end{tabular}

Vacuum - ejection filtering using large mud volumes loading (recommended)

Drinking water supply is the most urgent issue in countryside, because of water wells, containing highly contaminated water [3-5].

According to the 2874-82 State standard [6] the iron content for drinking water should not exceed $0.3 \mathrm{mg} / \mathrm{dm}^{3}$. However, in most cases, the underground water iron ratio exceeds the permissible concentration. For example, about $82 \%$ of Zhytomyr region's wells contain subsoil water, exceeding iron permissible standard $\left(0.4-3.23 \mathrm{mg} / \mathrm{dm}^{3}\right)$. The reason for this may be relatively high corrosivity of the subsoil water. Sod-podzol soils of Radomyshl and Chervonoarmiysk districts have acid reaction because of iron compounds. This requires liming to improve conditions of crops cultivation. When water - bearing horizons are fed by rivers and swamps, such waters contain iron in the form of compound with organic substances (e.g. Yemilchine district (20 rivers, swamps), Radomyshl district (15 rivers, swamps), and Baranivska district (17 rivers)). Meantime, the subsoil waters are acid in the ore and core mineral areas, such as Volodarsk-Volynskyy and Korosten districs, and this is the evidence of iron migration. Minor concentrations of iron in the subsoil waters of Chervonoarmiysk and Chernyakhiv regions can be explained by its more alkaline condition, widespread presence of oxygen in the waters and good aeration of strata lying above the subsoil water level [7].

\section{MATERIALS AND RESEARCH METHODS}

Natural waters contain various forms and content of iron. Therefore, it was necessary to develop a number of water deironing technologies. Available deironing technologies include the following methods:

- Reagent;

- Reagentless;

- Cation - exchange;

- Biochemical.

The surface water deironing is performed using reagent methods, while non-reagent methods are most commonly used for subsoil waters [8-13].

Currently, there is no single and flexible method for subsoil waters deironing. Each of these methods is used in certain cases and has its advantages and disadvantages.

\section{RESULTS AND DISCUSSION}

One of the most accessible and effective water deironing methods used in the modern water treatment systems is the water aeration based technology. The water aeration technology is based on the ability of iron and dis- 
solved oxygen containing water (II) to separate iron on grains surface, creating catalytic layer of the bivalent and trivalent iron oxide ions when filtering through the grains layer.

The main objective during water treatment is determination of the workflow rational parameters. The modelling water with iron content of $4.5 \mathrm{mg} / \mathrm{dm}^{3}$ was prepared to study the deironing kinetics. It is generally known that the water aeration process can continue for a long time. During experimentation, the air volume discharge rate was varied to speed up the process. The intensity of bubbling was regulated using replaceable micro air pumps, having air flow rates of $1.0 \mathrm{dm}^{3} / \mathrm{min}, 1.25,1.5$, 1.75, 2.0 and $2.5 \mathrm{dm}^{3} / \mathrm{min}$. Fig. 1 illustrates the dependence of iron content on the intensity of bubbling (Fig. 1).

The diagram shows that the more intensive is air supply the better is deironing process. Water bubbling was carried out within $30 \mathrm{mi}-$ nutes, varying air supply intensity. Water sampling and iron determination were performed every 5 minutes. Iron content variation in subsoil water is illustrated on fig. 2. This diagram shows the sanity standard after 20 minutes with air injection intensity of $2.5 \mathrm{dm}^{3} / \mathrm{min}$.

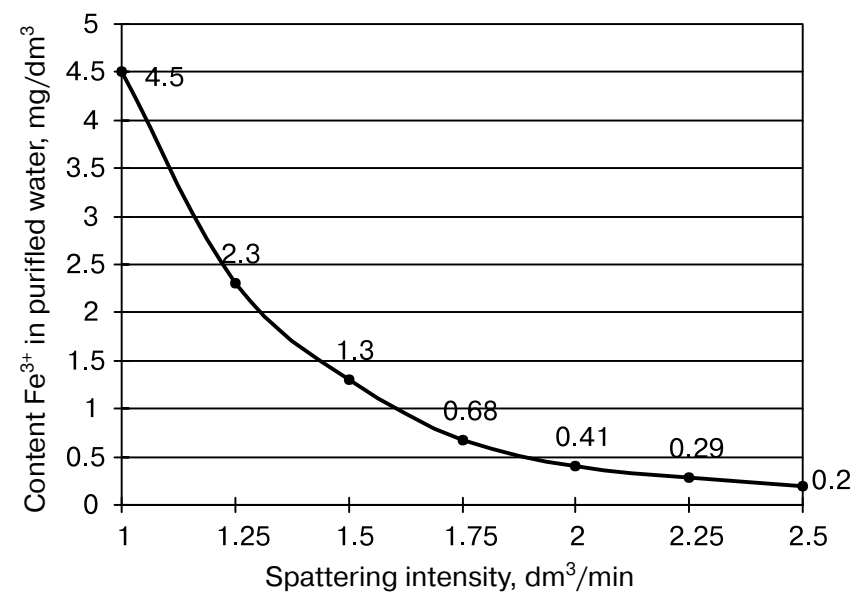

Figure 1. Dependence of iron content in purified water on the intensity of bubbling

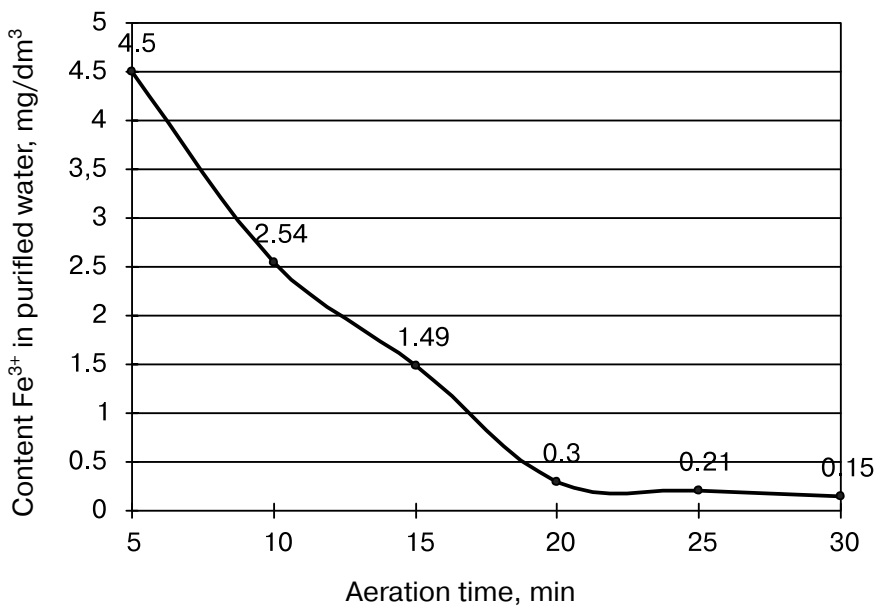

Figure 2. Dependence of iron content in purified water on the duration of aeration 
The second part of the experiment studies the subsoil water deironing process, when water is filtered through a layer of granular material. The quartz sand was used as the granular charge with the grain size of $0.5 \mathrm{~mm}$. Water detention time in the test vessel was 60 minutes. Filtering medium, intended for filter loading, should have necessary porosity, sufficient mechanical resistance against abrasion and chemical stability against water soluble action. As the sand meets all these requirements, it was cleaned and thoroughly washed to be used as the granular load. The depth of granular material layer was varied within 5-20 cm (Fig. 3).

It is generally known that grains size tightly related to filtration effectiveness. Therefore, apart from the depth of the sand layer, the grains size of filtering load was also varied. The sand fraction varied within the following ranges: $0.5-1.0 \mathrm{~mm} ; 1.0-1.5 \mathrm{~mm}$; $1.5-2.0 \mathrm{~mm} ; 2.0-2.5 \mathrm{~mm}$ and $2.5-3.0 \mathrm{~mm}$. Gradual decrease of iron concentration in the tested water from $4.5 \mathrm{mg} / \mathrm{dm}^{3}$ to $0.23 \mathrm{mg} / \mathrm{dm}^{3}$ was noted within relatively short time interval (Fig. 4) after increasing the depth of granular

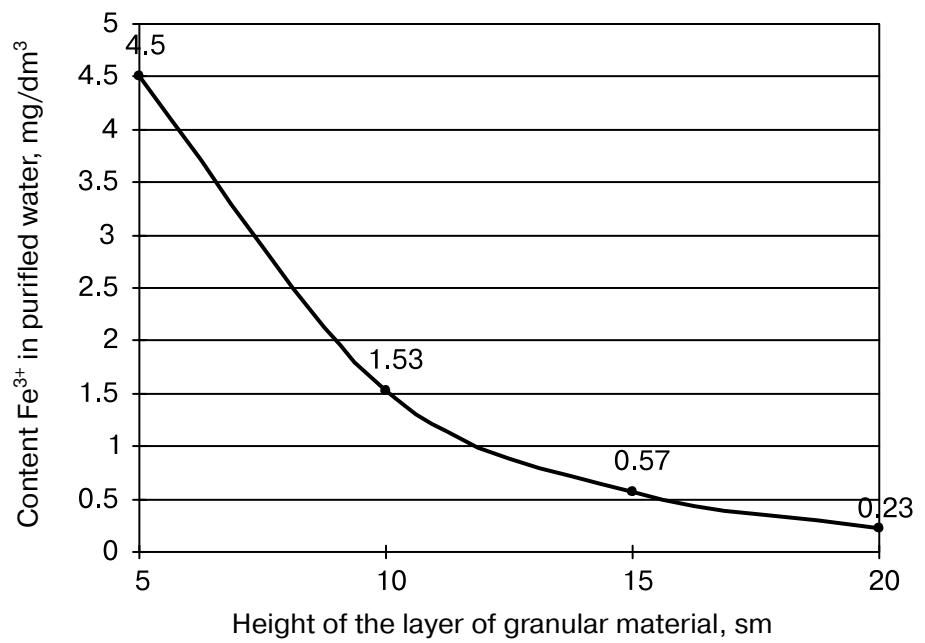

Figure 3. Dependence of iron content in purified water on the height of the granular material in the filter

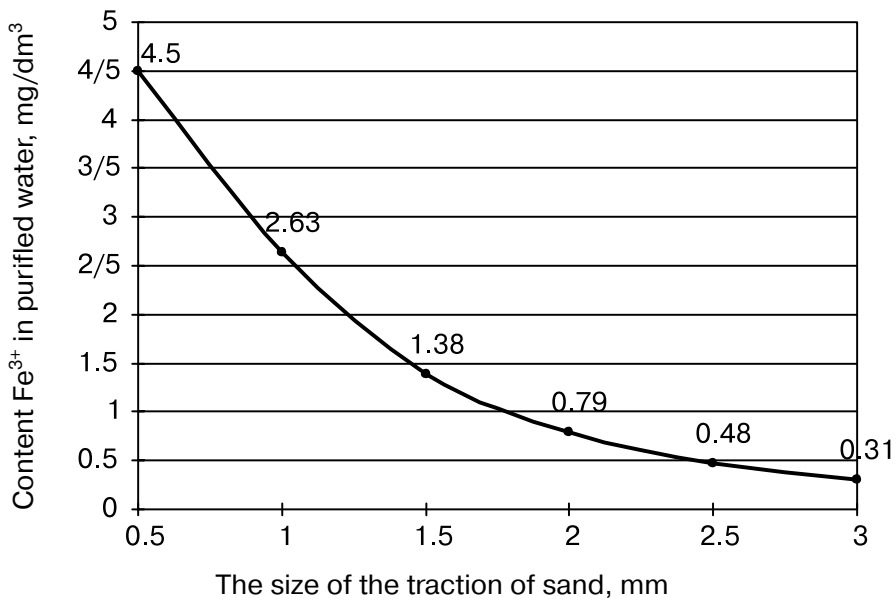

Figure 4. Dependence of iron content in purified water on the size of sand fractions 


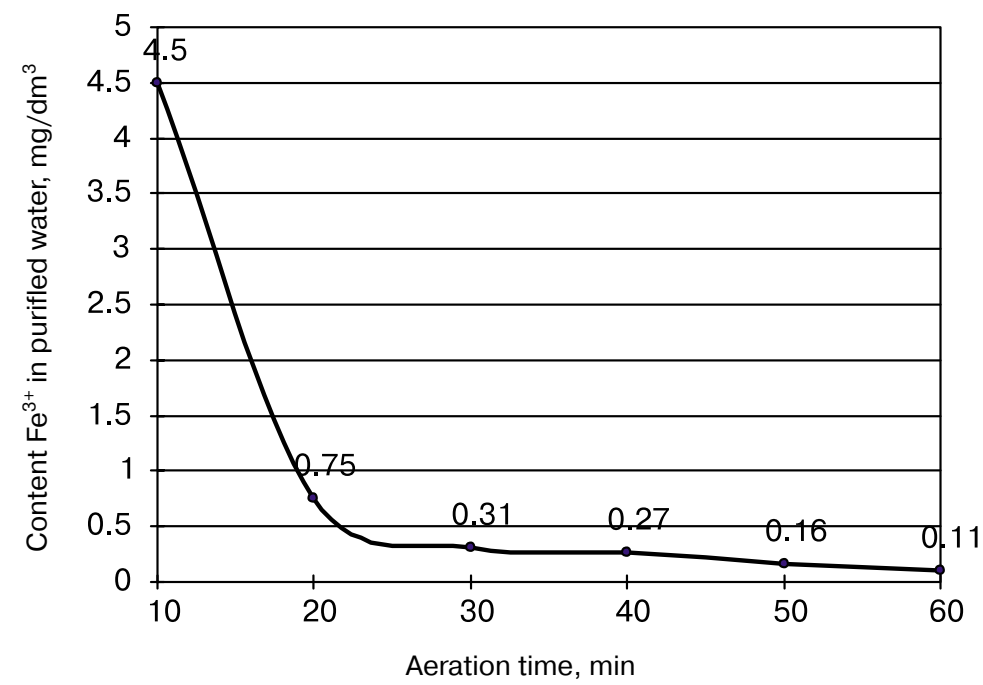

Figure 5. Dependence of iron content in purified water on the duration of aeration during filtration

material layer. Due to formation of catalytic film of iron oxides on the surface of grains, the content of iron was very close to $\ll 0 »$ and this can be seen on fig. 5 (dependence of iron concentration on duration of aeration).

\section{CONCLUSION}

It was determined that within the range of specified parameters, such as duration and intensity of aeration, layer depth and filtration load granules size, the process water aeration and filtration decreases iron compound to $0.15 \mathrm{mg} / \mathrm{dm}^{3}$, provided that:

- bubbling duration is 5-30 min;
- oxygen supply intensity varies between 1.0 to $2.5 \mathrm{dm}^{3} / \mathrm{min}$, and complies the sanity standards, allowing its household use.

Based on the results of studies, the following deironing optimal parameters can be recommended:

- air bubbling rate $25 \mathrm{dm}^{3} / \mathrm{min}$;

- duration of aeration - $20 \mathrm{~min}$;

- fractional composition of the sand 2.5-3 mm;

- fractional composition of sand - 2.5$3 \mathrm{~mm}$, $20 \mathrm{~cm}$.

- height of the sand layer - from 5 to

\section{ЛІТЕРАТУРА}

1. Яцик А.В. Екологічна ситуація в Україні і шляхи iï поліпшення / А.В. Яцик. - К.: Оріяни, 2003. $-84 \mathrm{c}$.

2. Гончарук B.B. SOS: питьевая вода / B.В. Гончарук // Химия и технология воды. -2010 . - № 5. C. $463-512$.

3. Мінаєва Н.Л. Знезалізнення підземних вод в баштах-колонах з пінополістирольним фільтром: Автореф. дис. ... канд. техн. наук: спец. 05.23.04 «Водопостачання, каналізація» / Н.Л. Міхаєва. - Рівне, 2010. - 21 с.

4. Гончарук B.B. Хімія води і проблеми питного водопостачання / В.В. Гончарук // Світогляд. -2009 . - № 4. - C. 18-28.

5. Запольський А.К. Водопостачання, водовідведення та якість води: підруч. / А.К. Запольський. - К.: Вища шк., 2005. - 671 с.
6. Якість води. Визначання заліза. Спектрометричний метод із використанням 1,10-фенантроліну: ДСТУ ISO 6332:2003. - [Чинний від 2003-07-05]. - К.: Держспоживстандарт України, 2003. - 7 с.

7. Про використання води в Україні та регіонах у 2015 році: статист. бюлетень / Державна служба статистики України. - К., 2016. - 18 с.

8. Орлов В.О. Знезалізнення підземних вод спрощеною аерацією та фільтруванням: монограф. / В.О. Орлов. - Рівне: НУВГП, 2008. - 158 с.

9. Чарний Д.В. Принципи хіміко-біологічного очищення підземних вод з багатокомпонентними забрудненнями / Д.В. Чарний, С.М. Мацелюк // Меліорація і водне господарство. - 2014. Вип. 101. - С. 281-292.

10. Физико-химические методы очистки воды. Управление водными ресурсами / [И. Астрелин, 
Е. Герасимов, А. Гироль и др.]. - К.: Проект «Water Harmony», 2015. - 614 c.

11. Хоружий П.Д. Ресурсозберігаючі технології водопостачання / П.Д. Хоружий, Т.П. Хомутецька, В.П. Хорунжий. - К.: Аграр. наука, 2008. $534 \mathrm{c}$.
12. Обезжелезивание природных вод [Електронний pecypc]. - Режим доступу: http://coolreferat. com

13. Закон України від 07.07.2011 р. «Про питну воду та питне водопостачання» // Відомості Верховної Ради України. - 2002. - № 16. - С. 112.

\section{REFERENCES}

1. Iatsyk, A.V. (2003). Ekolohichna sytuatsiia v Ukraini i shliakhy yii polipshennia [Ecological situation in Ukraine and ways to improve it]. Kyiv: Oriiany [in Ukrainian].

2. Goncharuk, V.V. (2010). SOS: pitevaia voda [SOS: drinking water]. Khimiia i tekhnologiia vody - Chemistry and technology of water, 5, 463-512 [in Russian].

3. Minaieva, N.L. (2010). Znezaliznennia pidzemnykh vod $\mathrm{v}$ bashtakh-kolonakh $\mathrm{z}$ pinopolistyrolnym filtrom [De-ironing ground water at the tower-column with polystyrene filler]. Extended abstract of candidate's thesis. Rivne [in Ukrainian].

4. Honcharuk, V.V. (2009). Khimiia vody i problemy pytnoho vodopostachannia [Chemistry of water and problems of drinking water supply]. Svitohliad - Outlook, 4, 18-28 [in Ukrainian].

5. Zapolskyi, A.K. (2005). Vodopostachannia, vodovidvedennia ta yakist vody [Water supply, drainage and water quality]. Kyiv: Vyshcha shkola [in Ukrainian].

6. Iakist vody. Vyznachannia zaliza. Spektrometrychnyi metod iz vykorystanniam 1,10-fenantrolinu [Water quality. Determination of iron Spectrometric method using 1,10-phenanthroline]. (2003). DSTU ISO 6332:2003 from $5^{\text {th }}$ July, 2003. Kyiv: Derzhspozhyvstandartu Ukrainy [in Ukrainian].

7. Pro vykorystannia vody $\mathrm{v}$ Ukraini ta rehionakh $\mathrm{u}$ 2015 rotsi: statyst. biuleten [About the use of water in Ukraine and regions in 2015: a statistical bulletin]. (2016). Derzhavna sluzhba statystyky Ukrainy. Kyiv [in Ukrainian].
8. Orlov, V.O. (2008). Znezaliznennia pidzemnykh vod sproshchenoiu aeratsiieiu ta filtruvanniam [Non-ironification of groundwater by aeration and filtration]. Rivne: NUVHP [in Ukrainian].

9. Charnyi, D.V., \& Matseliuk, Ie.M. (2014). Pryntsypy khimiko-biolohichnoho ochyshchennia pidzemnykh vod z bahatokomponentnymy zabrudnenniamy [Principles of chemical and biological purification of groundwater with multicomponent pollution]. Melioratsiia $i$ vodne hospodarstvo - Reclamation and water management, 101, 281-292 [in Ukrainian].

10. Astrelin, I., Gerasimov, E., Girol, A., Girol, N., Eshchenko, L., \& Zhekeev, M. et al. (2015). Fizikokhimicheskie metody ochistki vody. Upravlenie vodnymi resursami [Physicochemical methods of water purification. Water resources management]. Kiev: Proekt «Water Harmony» [in Russian].

11. Khoruzhyi, P.D., Khomutetsъka T.P., \& Khoruzhyi, V.P. (2008). Resursozberihaiuchi tekhnolohii vodopostachannia [Resource-saving water supply technologies]. Kyiv: Ahrarna nauka [in Ukrainian].

12. Obezzhelezivanie prirodnykh vod [Iron removal of natural waters]. coolreferat.com. Retrieved from http://coolreferat.com [in Russian].

13. Zakon Ukrainy «Pro pytnu vodu ta pytne vodopostachannia» vid 07.07.2011 [Law of Ukraine «About drinking water and drinking water» from July 7th, 2011]. (2002). Vidomosti Verkhovnoi Rady Ukrainy - Information from the Verkhovna Rada of Ukraine, 16, 112 [in Ukrainian]. 